\title{
A NÖI NEMI HORMONOK SZINTJE ÉS A TESTZSÍROSSÁG KAPCSOLATA PUBERTÁSKORÚ LEÁNYOKNÁL
}

\author{
Bodzsár Éva ${ }^{1}$, Fehér Virág Piroska ${ }^{1}$, Vadászi Henrietta ${ }^{2}$ és Zsákai Annamária ${ }^{1}$ \\ ${ }^{1}$ Eötvös Loránd Tudományegyetem, Embertani Tanszék, Budapest; \\ ${ }^{2}$ Eötvös Loránd Tudományegyetem, Biokémiai Tanszék, Budapest
}

Bodzsár É., Fehér V. P., Vadászi H., Zsákai A.: Sex hormonal levels and body fatness in pubertal girls. The main aims of the study were (1) to determine the normal range of salivary oestrogen and progesterone levels in subadult women by describing the pubertal pattern of gonadal sex hormone secretion; (2) to analyse the relationship between sex hormonal levels and body fat mass and body fat distribution in girls in the studied age interval; and (3) to analyse the relationship between body fatness and sexual maturation type by identifying early, average and late maturing girls on the basis of sex hormone levels, breast development and the occurrence of menarche.

Hormonal and anthropomorphic data in girls across the pubertal spectrum (n: 100 girls, aged between 7 and 17 years) were collected in a cross-sectional study in 2016. The body fat fraction was estimated by InBody 720 body impedance analyser. The waist-to-hip ratio was used to assess the body fat distribution. The levels of free estradiol and free progesterone hormones were estimated by the 17 $\beta$-Estradiol and Progesterone Saliva ELISA kits of IBL (Hamburg, Germany). A shift toward an increased level of salivary estradiol was found from the age 11, while the level of progesterone monotonically increased earlier from the age of 8 in the studied sample of healthy girls. By considering the relationship between body fatness indicators and gonadal hormonal levels, it can be stated that body fat mass significantly related to the level of salivary estradiol in the studied age interval of girls, the higher the level of estradiol, the higher amount of body fat was found. The body fat distribution did not show relation to the salivary level of the studied gonadal hormones in girls. The later the sexual maturation, the smaller amount of body fat mass was found in the studied age interval.

Keywords: Sexual maturation; Body fatness; Sex hormonal levels; Pubertal girls.

\section{Bevezetés}

A testzsír mennyiségében és eloszlásában pubertáskortól kezdve jelentős különbség mutatható ki a két nem között, amely nemi különbség kialakulásáért és fenntartásáért a nemi hormonok termelödésének nemi különbségei felelősek (Rosenbaum és Leibel 1999, Wells 2007, Kaplowitz 2008). Mindezt igazolja az a megfigyelés is, hogy a nők ún. reprodukciós stádiumainak (pre-, peri- és posztreproduktív stádiumok, illetve a terhességek és a szoptatások időszakai) átmeneteit kísérő nemi hormonok elválasztásában megjelenő jelentős változásokat a testzsír frakció mennyiségének és a testtájékokon való elrendeződési mintázatának változásai is jellemzik (Zöllner és mtsai 2005, Dennis 2007, Gallagher 2007, Shuster és mtsai 2010, Zsákai és mtsai 2015). A testzsírosság és az endokrin státusz közötti kapcsolatrendszer komplexitásához azonban még az az összefüggés is hozzájárul, hogy a relatív zsírtömeg és a szabad ösztrogénhormonok 
koncentrációja között, a zsírszövet ösztrogéntermelö funkciója következtében is szoros a kapcsolat (Behl 2002, Kershaw és Flier 2004).

Bár ezt a testzsírosság mutatói és a női nemi hormonok szintje közötti összetett kapcsolatrendszert már nagyszámú összetevője tekintetében ismerjük, azonban a rendszer további számos kapcsolata még nem ismert, különösen igaz ez a pubertáskorú leányok testszerkezete és endokrin státusza közötti kapcsolatok esetében. Az auxológiai vizsgálatok egyértelmüen igazolták már a gyermekkori tápláltsági státusz és a pubertáskor időzítettsége közötti szoros összefüggést, azaz a túltáplált, kövér leányok átlagostól korábbi nemi érését, illetve az alultáplált leányok átlagostól későbbi nemi érését (Bodzsár 1977, 1991, 2001, Pápai 1996, Sandhu és mtsai 2006).

A vizsgálat fö célkitüzései között szerepelt (1) az ösztrogén és progeszteron hormonok nyálbeli koncentrációja pubertáskori normál tartományainak meghatározása a két női nemi hormon vizsgált életkori intervallumban leányokra jellemző termelődési mintázatának elemzésével, (2) a testzsír tömege és eloszlása valamint a nemi hormonok szintje közötti kapcsolatrendszer elemzése pubertáskorú leányoknál, illetve (3) a leányoknál a nemi hormonok nyálbeli koncentrációja, az emlők fejlettsége és a menarchekor ill. menarche bekövetkezte alapján kialakított nemi érési típus alcsoportok testzsírossága mutatóinak összehasonlítása a nemi érési típus és a testzsírosság kapcsolatának elemzésére.

\section{Vizsgált személyek és alkalmazott módszerek}

A vizsgálat mintájául szolgáló 7-17 éves leányok (n: 100 fő) testszerkezeti vizsgálatát és endokrin státuszuk becslését 2016-ban végeztük el. A gyermekek testzsír frakcióját bőrellenállás-mérésen alapuló testösszetétel-analizátorral becsültük (InBody 720 müszer, Biospace, Los Angeles, USA). A testzsír-eloszlás becslésére a WHO (2008) javaslatát követve a derékkerület-csípőkerület arányt (WHR indext) használtuk. A már menstruáló leányok esetében a menstruációs történet adataira vonatkozóan személyes interjúk során, kérdőívek segítségével gyüjtöttünk adatot. A menarchekorra vonatkozóan retrospektív módszer segítségével történt az adatgyüjtés. Az emlők fejlettségét a Tanner-féle (1962) stádiumok meghatározásával becsültük. A leányok nemi érési típus alcsoportokba (korán, átlagosan, későn érők alcsoportjaiba) sorolását az első menstruáció bekövetkezte, életkora és az emlők fejlettsége figyelembe vételével a Második Országos vizsgálat (Bodzsár és Zsákai 2012) eredményei alapján megszerkesztett, hazai referencia-sorozatok tükrében (átlagos nemi érési típusúaknak tekintettük azokat, akiknek a menarchekora a referenciamedián \pm 2 év intervallumon belüli volt, illetve akiknél az emlők fejlettsége az adott fejlettségi stádium mediánja \pm 1 év intervallumba tartozott), valamint az ösztrogén (17ß-ösztradiol) nyálbeli koncentrációja és a hormon termelődésének vizsgált mintára jellemző életkori centilis-mintázata alapján (normál hormonszintnek az életkornak megfelelő 10. és a 90. centilis közötti tartományba sorolható koncentrációkat tekintettük) végeztük el. Abban az esetben, hogy ha a nemi érési típus ezen indikátorai alapján történő alcsoportba-sorolás eltérő eredményre vezetett, a vizsgált leány adatait kihagytuk az elemzéseinkből (összesen 2 ilyen gyermek szerepelt a vizsgálatban).

A már menstruáló leányoktól a menstruációs ciklusuk korai follikuláris fázisában (1-4. nap), a még nem menstruáló leányoktól a vizsgálat napján gyüjtöttünk nyálmintát (2 ml-t). A gyüjtött nyálmintákban a nemi hormonok (szabad) szintjét az IBL GmbH (Hamburg, Németország) 17ß-Estradiol (RE52601) és Progesterone (RE52281) Saliva 
ELISA kitjeinek segítségével becsültük. A mintagyüjtés a gyártó által forgalmazott mintagyüjtő tubusukba sztenderd módon történt. A hormonok nyálbéli koncentrációjának meghatározása, amely során is a gyártó által meghatározott sztenderd vizsgálati protokollt követtük, a mintavételt követő maximum 2 héten belül megtörtént. A minták abszorbanciáját 450 nm-en határoztuk meg (Epoch 267860 típusú fotométerrel).

A statisztikai elemzéseket az SPSS v. 20 programcsomaggal végeztük. Hipotéziseinket 5\%-os szinten teszteltük. A nemi hormonok koncentrációjának centilismintázatait az lmsChartMaker Pro 2.3 (Medical Research Council, UK 1997-2006) szoftverrel szerkesztettük meg. Az általánosított lineáris modell segítségével elemeztük a kapcsolatrendszert a testzsírosság mutatói és a feltételezett becslő tényezőik között. Az egyedi zsírtömeg értékek z-értékeit a korcsoportos átlag és szórás értékeinek felhasználásával számoltuk ki.

\section{Vizsgálati eredmények és értékelésük}

A vizsgált nemi hormonok termelödésének életkori mintázata

Az ösztrogén termelődésének vizsgált mintára jellemző életkori mintázatát figyelembe véve megállapítható, hogy 11 éves korig a hormon nagyon alacsony nyálbeli szintje jellemző a leányoknál, majd átlagosan 11 éves kortól egy monoton növekedés tapasztalható termelődésében, majd az ösztrogén szintje életkorral előrehaladó emelkedésének lassulása figyelhető meg 13 éves kortól (1. ábra). Az ösztrogén hormon nyálbeli koncentrációjának normál tartománya a nők 19-50 éves korcsoportjában 0,6-6,3 pg/ml, míg a posztmenopauzális státuszú nők esetében 0,6-3,1 pg/ml az IBL ajánlásai szerint (http://www.ibl-international.com, IBL 2016). A hormon 7-17 éves leányok vizsgált mintájára jellemző centilis-mintázatát értékelve, a 10. és 90. centiliseket, mint a normál tartomány kijelölésére alkalmas centilis-párt figyelembe véve megállapítható, hogy a 7,0-11,9 évesek korcsoportjában a 0,9-4,8 pg/ml-t, míg a 12,0-17,0 évesek korcsoportjában (a menstruációs ciklus korai follikuláris fázisában) 1,1-5,9 pg/ml-t ajánlhatjuk a leányok vizsgált korcsoportjaiban normál tartományokként az ösztrogén nyálbeli koncentrációjának vizsgálatakor.

A progeszteron hormon nyálbeli koncentrációja esetében a leányok 8 éves korától kezdve egy monoton növekedés figyelhető meg az életkor előrehaladtával, amely növekedés lassulását tapasztaltuk a leányok esetében átlagosan 12 éves kortól (1. ábra). A progeszteron nyálbeli koncentrációjának normál tartományát az IBL (http://www.iblinternational.com, IBL 2016) 28-82 pg/ml-ben határozta meg a 20 évestől idősebb premenopauzális státuszú nők csoportjára, míg 18-51 pg/ml-ben a posztmenopauzális státuszú nők csoportjára. A vizsgált mintára jellemző centilis-mintázat alapján (ezúttal is a 10. és 90 . centilisek értékeit figyelembe véve) a 7,9 évestől fiatalabb leányok esetében 21-46 pg/ml, 8,0-11,9 évesek korcsoportjában a 22-59 pg/ml, míg a 12,0-17,0 éves leányok esetében (a korai follikuláris fázisban) a 25-67 pg/ml nyálbeli koncentrációkat tudjuk ajánlani normál tartományként a hormon nyálbeli koncentrációjának értékelésekor.

\section{A nemi érettségi státusz és a nemi hormonok koncentrációja}

Az ösztrogén nyálbeli koncentrációjában az emlők B1- és B2-es Tanner-féle fejlettségi stádiumába sorolt leányok esetében nem mutatható jelentős különbség, az esetükben a fejlettebb stádiumokba sorolt leányokra jellemző hormon-koncentrációktól alacsonyabb ösztrogén-koncentráció jellemezte ezt a két alcsoportot (2. ábra). A B3-as 
stádiumtól kezdve a leányok nyálbeli ösztrogén-koncentrációja az emlők fejlettségének elörehaldtával fokozatosan egyre nagyobb volt, legnagyobb koncentrációbeli különbség a B4- és B5-ös stádiumba soroltak alcsoportjai között volt igazolható. A progeszteron hormon nyálbeli szintje az emlők B4-es stádiumának alcsoportjáig stabil volt a vizsgált mintában, jelentős különbséget az emlők fejlettsége alapján kialakított alcsoportok között csak a B4-es és B5-ös alcsoportok között tudtunk igazolni, a kifejlett emlökkel jellemezhető leányok alcsoportjában volt a legnagyobb a progeszteron nyálbeli koncentrációja (2. ábra).
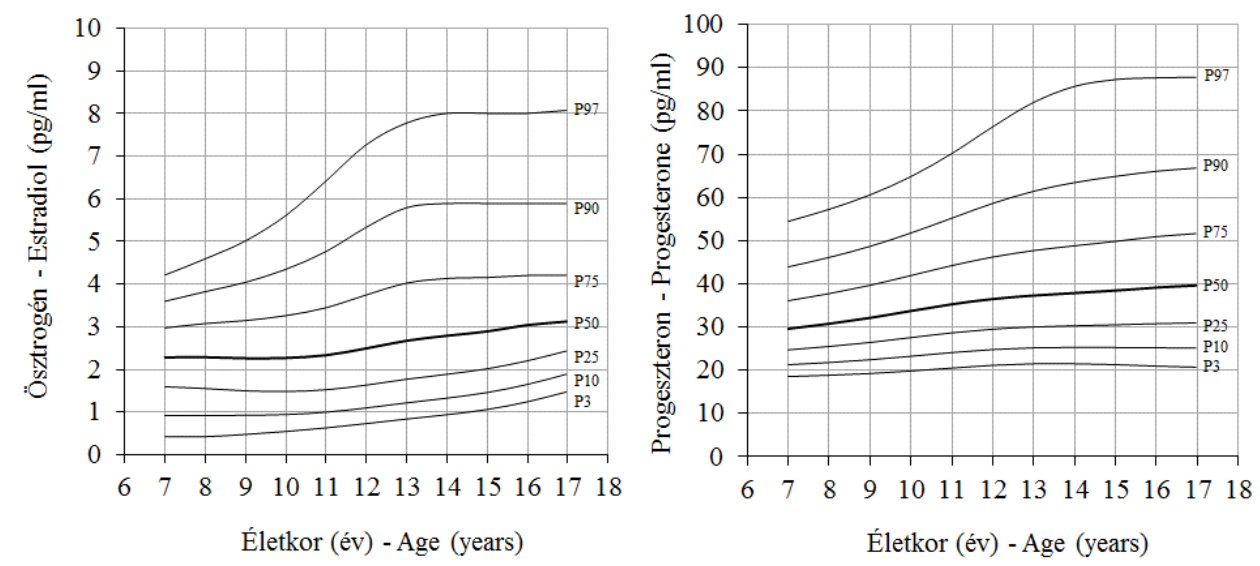

1. ábra: A vizsgált nemi hormonok nyálbeli koncentrációjának centilis-mintázata 7-17 leányoknál.

Fig. 1: Centile distribution of salivary sex hormone levels in girls between 7 and 17 years of age.

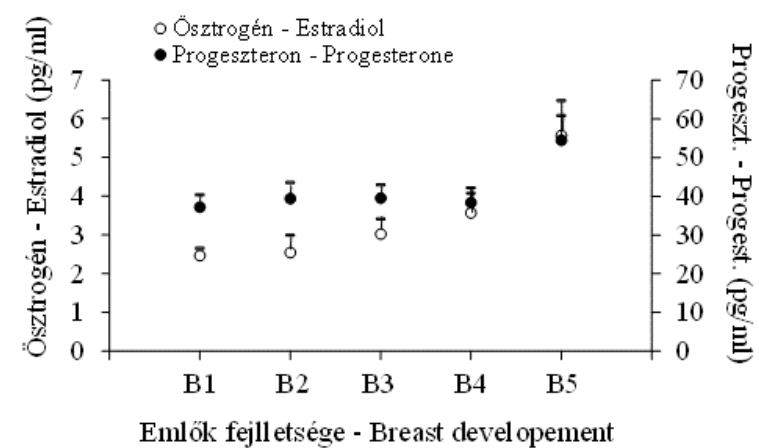

2. ábra: A nemi hormonok átlagos koncentrációja (+SE) az emlők fejlettségi állapota (Tanner 1962) szerint kialakított alcsoportjaiban (szignifikáns különbségek: ösztrogén - B1-B5 $p=0,003$, B2-B5 p=0,015, B3-B5 p=0,048, progeszteron - B1-B5 p=0,027, B4-B5 p=0,023; ANOVA).

Fig. 2: Sex hormone levels (mean+SE) in girls by breast development stage (Tanner 1962; significant differences: estradiol $-\mathrm{B} 1-\mathrm{B} 5 \mathrm{p}=0.003$, B2-B5 $\mathrm{p}=0.015$, B3-B5 $\mathrm{p}=0.048$, progesterone - B1-B5 p=0.027, B4-B5 p=0.023; ANOVA).

A testzsírosság és a nemi hormonok koncentrációja

Bár a feltételezetten a zsíreloszlást befolyásoló tényezök (életkor, nemi hormon nyálbeli koncentrációja, emlők fejlettsége) és a WHR mutató közötti kapcsolatrendszer 
megismerése céljából illesztett, ún. általánosított lineáris modell összességében szignifikáns volt, a becslő tényezők egyikének egyedi hatása sem érte el az 5\%-os szignifikancia szintet (1. táblázat), egyikőjük esetében sem beszélhetünk a zsíreloszlásra gyakorolt jelentős hatásról. Ezzel szemben a zsírtömeg feltételezett becslő tényezői közül a progeszteron-szint kivételével mindegyik, tehát az életkor, az ösztrogén-szint és az emlök fejlettségi szintje is jelentős kapcsolatot mutatott a zsírtömeggel (2. táblázat). A további elemzéseinkben az életkor és a nemi érettségi státusz hatását kiküszöbölendö az egyedi testzsírtömegeket illetve ösztrogén-szinteket z-értékekbe transzformáltuk át, illetve az emlök fejlettségi stádiumai szerint külön-külön végeztük el az ösztrogén-szint és a testzsírtömeg közötti kapcsolat elemzését. A két vizsgált változó közötti korreláció tendenciáját tekintve pozitív volt az emlők fejlettsége alapján kialakított alcsoportokban, tehát minél nagyobb az ösztrogén-hormon szabad nyálbeli koncentrációja, annál nagyobb a leányok zsírtömege, szignifikáns kapcsolatot közöttük azonban csak a B1-es és B4-es stádiumokban tudtunk igazolni (4. ábra).

1. táblázat. A testzsírtömeg, ill. -eloszlás és a feltételezett becslö tényezőik közötti kapcsolat megismerése céljából végzett általánosított lineáris modell tényezőinek szignifikancia szintjei (szignifikáns értékek dőlten szedve szerepelnek) és a becslés determinációs együtthatója $\left(\mathrm{R}^{2}\right)$. Table 1. Significance levels (values in italic are significant at $5 \%$ level of random error) and the coefficient of determination $\left(\mathrm{R}^{2}\right)$ in tests of between-subjects effect in general linear model for WHR and fat mass as dependent variables.

\begin{tabular}{|c|c|c|}
\hline Tényezők - Factors & WHR & Testzsírtömeg - Fat mass (kg) \\
\hline Modell - Model & 0,002 & 0,001 \\
\hline Tengelymetszet - Intercept & 0,001 & 0,192 \\
\hline Ösztrogén-szint - Estradiol level (pg/ml) & 0,633 & 0,048 \\
\hline Progeszteron-szint - Progesterone level (pg/ml) & 0,881 & 0,096 \\
\hline Életkor (év) - Age (years) & 0,262 & 0,035 \\
\hline \multirow[t]{2}{*}{ Emlők fejlettsége - Breast development } & 0,556 & 0,039 \\
\hline & 0,234 & 0,552 \\
\hline
\end{tabular}

2. táblázat. A testzsírtömeg ( $\mathrm{kg}$ ) becslésére alkalmazott általánosított lineáris modell paraméterei (referencia-kategória: B5 fejlettségi stádium; dőlten szedett p-értékek szignifikánsak).

Table 2. Parameter estimates in general linear model fitted to fat mass (kg; B5 breast development stage was the reference category; $\mathrm{p}$ values in italic are significant at $5 \%$ level of random error).

\begin{tabular}{lcccrr}
\hline Tényezők - Factors & B & SE & p & \multicolumn{2}{c}{$95 \%$ CI } \\
\hline Tengelymetszet - Intercept & 6,310 & 4,802 & 0,192 & $-3,235$ & 15,854 \\
Ösztrogén-szint - Estradiol level (pg/ml) & 0,287 & 0,022 & 0,048 & $-0,153$ & 0,428 \\
Progeszteron-szint - Progest. level (pg/ml) & $-0,031$ & 0,017 & 0,096 & $-0,066$ & 0,003 \\
Életkor (év) - Age (years) & 0,597 & 0,279 & 0,035 & 0,042 & 1,152 \\
B1 & $-5,030$ & 2,360 & 0,036 & $-9,720$ & $-0,339$ \\
B2 & $-3,375$ & 2,201 & 0,029 & $-7,750$ & 0,999 \\
B3 & $-5,115$ & 1,771 & 0,005 & $-8,635$ & $-1,594$ \\
B4 & $-1,857$ & 1,783 & 0,051 & $-3,401$ & 1,687 \\
\hline
\end{tabular}

B1-B4: emlők Tanner-féle fejlettségi stádiumai - Tanner stages of breast development, B: béta - beta, SE: átlag hibája - standard error, p: szignifikancia-szint - significance level, 95\% CI: 95\%-os konfidenciaintervallum - 95\% confidence interval 


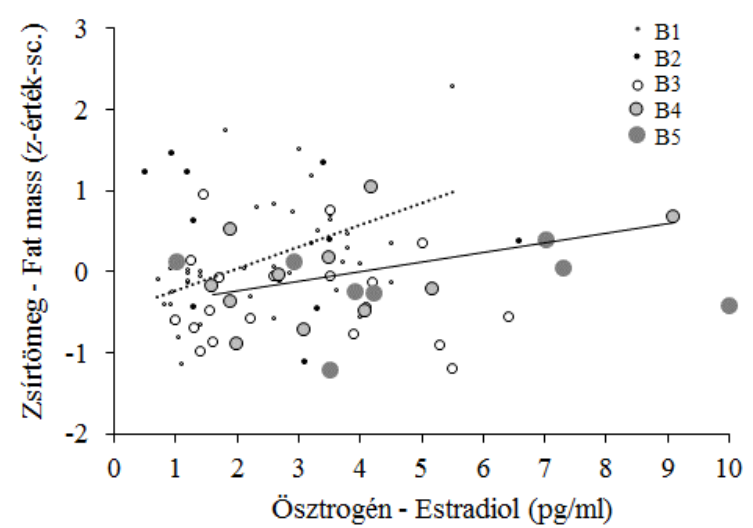

4. ábra: A testzsírtömeg egyedi z-értékei (kg) az ösztrogén-szint függvényében az emlők fejlettsége alapján kialakított alcsoportokban (regressziós egyenletek: - - -: B1 - zsírtömeg z-értéke = 0,270×ösztrogén-szint - 0,507, $\mathrm{R}^{2}=0,348,-$ : B4 - zsírtömeg z-értéke $=0,119 \times$ ösztrogén-szint $\left.0,480, R^{2}=0,287\right)$.

Fig. 4: Individual z-scores of fat mas (kg) to estradiol level by breast development stages (regression equations: B1 - fat mass ( $\mathrm{z}$-score) $=0.270 \times$ estradiol level $-0.507, \mathrm{R}^{2}=0.348, \ldots$ : B4 fat mass z-score $=0.119 \times$ estradiol level $-0.480, \mathrm{R}^{2}=0.287$ ).

A tápláltsági állapot és az ösztrogén hormon koncentrációja

A leányok különböző tápláltsági állapotú alcsoportjaiban mért átlagos ösztrogénszinteket elemezve megállapítható, hogy a rosszul táplált leányok nyálbeli szabad ösztrogén-szintje alacsonyabb volt, mint a normált tápláltsági állapotú, illetve túlsúlyos leányoké (5. ábra).

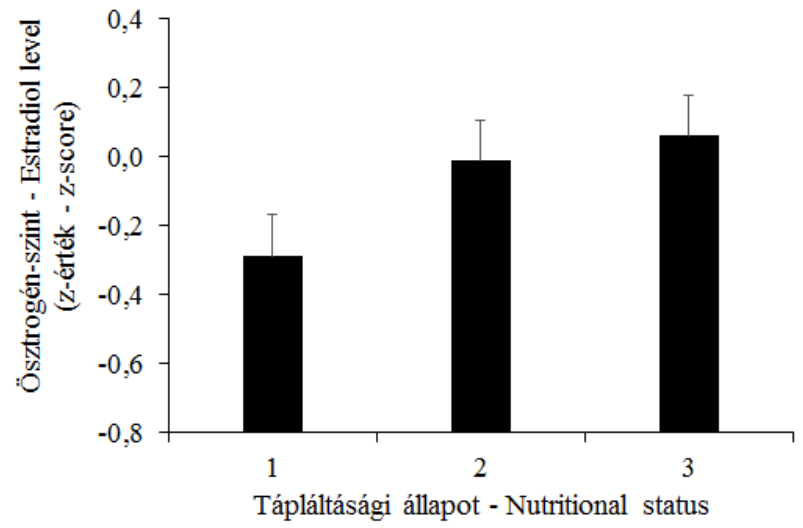

5. ábra: Az átlagos (+SE) ösztrogén-szint z-értékei a leányok tápláltsági állapota szerint (1: rosszul tápláltak, 2: normál tápláltsági állapotúak, 3: túlsúlyosak/kövérek; $\mathrm{p}<0,05$, ANOVA).

Fig. 5: Mean (+SE) z-score of estradiol level by nutritional type in girls (1: underweight, 2: normal nutritional status, 3: overweight and obese; $\mathrm{p}<0.05$, ANOVA). 
A nemi érési típus és a testzsírosság

A leányok átlagos testzsírtömege jelentősen különbözött a nemi érési típus szerint kialakított alcsoportokban, a relatíve korai nemi érésủ leányok testzsírtömegének z-értéke volt átlagosan a legnagyobb, míg a relatíve későn érő típusúaké a legkisebb (6. ábra). A testzsír-eloszlás jellemzésére használt WHR index z-értéke is különbözött a nemi érési típus alcsoportokban, ugyanis a relatíve későn érő típusú leányok WHR indexének átlagos z-értéke meghaladta a másik két nemi érési típusba sorolt leányok átlagos z-értékét, amely két alcsoport WHR index z-értéke között nem igazolható jelentős különbség (6. ábra).
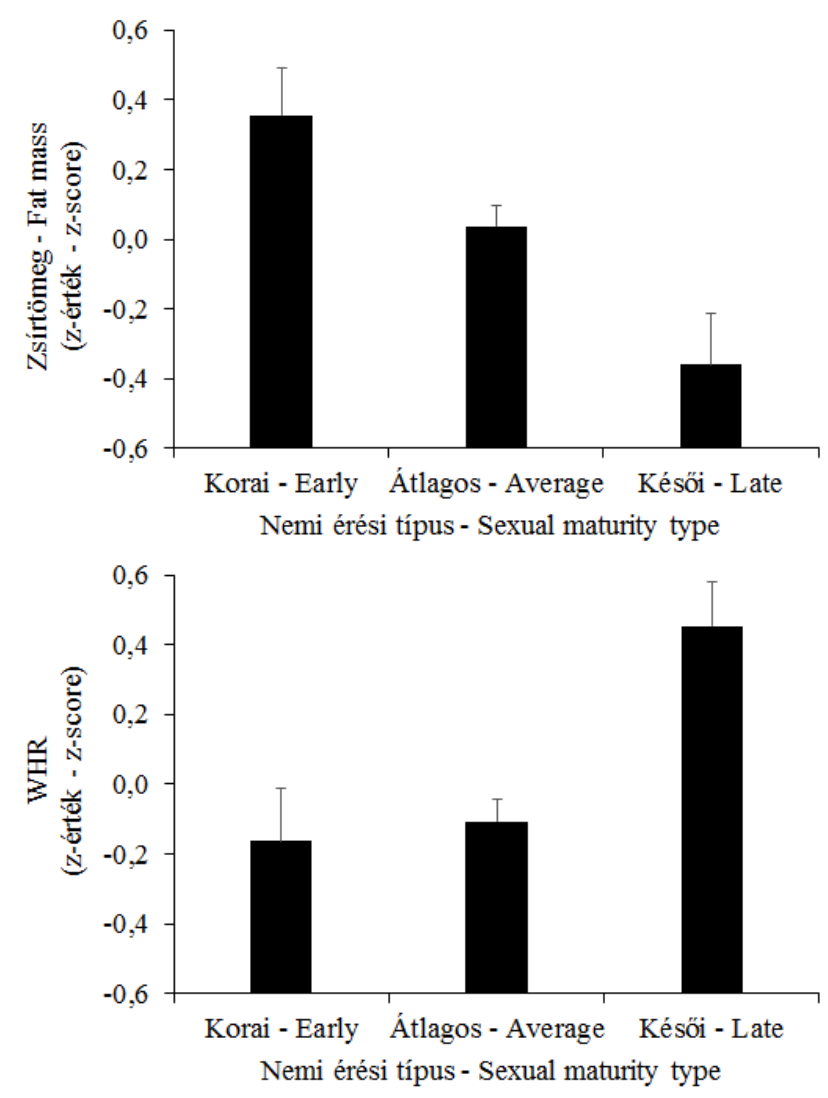

6. ábra: A testzsír mutatóinak átlagos (+SE) z-értékei a leányok nemi érési típus szerint kialakított alcsoportjaiban (ANOVA - zsírtömeg z-értéke: p=0,004, WHR z-értéke: p=0,020).

Fig. 6: Mean (+SE) z-score of fatness indicators by sexual maturation type (ANOVA - fat mass zscore: $\mathrm{p}=0.004$, WHR z-score: $\mathrm{p}=0.020$ ).

\section{Következtetések}

A pubertáskorú leányok testzsírosságának mutatói és endokrin státuszuk közötti kapcsolatrendszer számos komponensét ismerjük már. A kapcsolatrendszer feltárására végzett vizsgálatok jelentős része különbözö nem érettségi státuszú leányok 
testösszetételének összehasonlító elemzésére épült (Bodzsar 1977, 2000, 2006, Roemmich és mtsai 1999, Kaplowitz és mtsai 2001, Davison és mtsai 2003, Kaplowitz 2008, Jasik és Lustig 2008), míg a testzsír tömege ill. eloszlása és a nemi hormonok szintje közötti kapcsolatot serdülőkorúak körében mindezidáig nagyon kevesen vizsgálták. E kevés vizsgálat között pedig nagyon kevés vizsgálat volt olyan, amelyet egészséges gyermekek körében végeztek. A leányok nemi érési típusa és a pubertáskori testzsír tömege és eloszlása között jelentős kapcsolatot igazoltak a korábbi auxológiai vizsgálatok (Bodzsár 1977, 1991, 2000, de Ridder és mtsai 1992, McCartney és mtsai 2007, Casazza és mtsai 2008, Zhai és mtsai 2015).

Vizsgálatunk eredményei alapján megállapítást nyert, hogy a szabad progeszteron nyálbeli koncentrációja jelentősen emelkedik 8 éves kortól, míg az ösztrogén esetében a hormon szabad formája koncentrációjának ezt a pubertáskori emelkedését csak 11 éves kortól tudtuk igazolni az egészséges leányok vizsgált mintájában. A nemi hormonok átlagos szintje az emlők fejlettségi stádiumai alapján kialakított nemi érettségi státusz alcsoportokban a fejlettségi fok előrehaladtával fokozódott, legnagyobb különbséget az egymást követö fejlettségi stádiumok között a B4-es és B5-ös stádiumok között tudtuk mindkét vizsgált nemi hormon esetében kimutatni.

A testzsírosság vizsgált indikátorai közül a testzsír tömege mutatott szoros kapcsolatot az ösztrogén nyálbeli koncentrációjával, minél nagyobb volt a nemi hormon koncentrációja, annál nagyobb volt a testzsír tömege a vizsgált leányok esetében.

A testzsírosság mutatói és a nemi érési típus közötti kapcsolat elemzésekor megállapíthattuk, hogy (1) leányok testzsírtömege és nemi érési típusa között szoros a kapcsolat, azaz minél későbbi a nemi érés, annál kisebb zsírtömeg jellemzi a pubertáskorú leányokat; illetve (2) hogy a késői nemi érési típusú leányoknál a tipikus nőies zsíreloszlás is jelentősen később alakul ki, mint a korán ill. átlagos tempóban érő leányoknál.

Köszönetnyilvánítás: A tanulmány a Bolyai János Kutatási Ösztöndíj támogatásával (ZsA, 20142017) készült.

\section{Irodalom}

Behl, C. (2002): Oestrogen as a neuroprotective hormone. Nat. Rev. Neurosci., 3(6): 433-442. DOI: $10.1038 / \mathrm{nrn} 846$

Bodzsár, É.B. (1977): Recent data to the physical development of adolescent girls. In: Growth and Development; Physique. pp. 177-189.

Bodzsár, É.B. (1991): The Bakony growth study. Humanbiologia Budapestinensis.

Bodzsár, É.B. (2000): Studies on sexual maturation of Hungarian children. Acta Biol. Szeged., 44(1-4): 155-165.

Bodzsár, É.B. (2006): Secular change in the growth and sexual maturation of Hungarian children. Int. J. Anthrop., 21(1): 25-32. DOI: 10.1007/s11599-006-9008-Z

Bodzsár, É., Zsákai, A. (2012): Magyar gyermekek és serdülök testfejlettségi állapota Országos Növekedésvizsgálat 2003-2006. Plantin Kiadó, Budapest. p. 240.

Casazza, K., Goran, M.I., Gower, B.A. (2008): Associations among insulin, estrogen, and fat mass gain over the pubertal transition in African-American and European pubertal development among girls at age 9. Pediatrics, 111(4): 815-821. DOI: $\underline{\text { 10.1210/jc.2007-2776 }}$ 
Davison, K.K., Susman, E.J., Birch, L.L. (2003): Percent body fat at age 5 predicts earlier American girls. J. Clin. Endocrin. Metab., 93(7): 2610-2615. DOI: 10.1210/jc.2007-2776

Dennis, K.E. (2007): Postmenopausal women and the health consequences of obesity. J. Obstet. Gynecol. Neonat. Nur., 36(5): 511-519. DOI: 10.1111/j.1552-6909.2007.00180.x

De Ridder, C.M., Bruning, P.F., Zonderland, M.L., Thijssen, J.H., Bonfrer, J.M., Blankenstein, M.A., Huisveld, I.A., Erich, W.B. (1990): Body fat mass and plasma hormones in early puberty in females. J. Clin. Endocrin. Metab., 70(4): 888-893. DOI: 10.1210/jcem-70-4-888

de Ridder, C.M., Thijssen, J.H., Bruning, P.F., Van den Brande, J.L., Zonderland, M.L., Erich, W.B. (1992): Body fat mass, body fat distribution, and pubertal development: a longitudinal study of physical and hormonal sexual maturation of girls. J. Clin. Endocrinol. Metab., 75: 442-446. DOI: $10.1210 /$ jcem.75.2.1639945

Gallagher, J.C. (2007): Effect of early menopause on bone mineral density and fractures. Menopause, 14(3): 567-571. DOI: 10.1097/gme.0b013e31804c793d

Jasik, C.B., Lustig, R.H. (2008) Adolescent obesity and puberty: the "perfect storm". Ann. NY Acad. Sci., 1135(1): 265-279. DOI: 10.1196/annals.1429.009

Kaplowitz. P.B. (2008): Link between body fat and the timing of puberty. Pediatrics, 121(Suppl 3): S208-S217. DOI: 10.1542/peds.2007-1813F

Kaplowitz. P.B., Slora, E., Wasserman, R.C., Pedlow, S.E., Herman-Giddens, M.E. (2001): Earlier onset of puberty in girls: relation to increased body mass index and race. Pediatrics, 108(2): 347-353. DOI: $10.1542 /$ peds.108.2.347

Kershaw, E.E., Flier, J.S. (2004): Adipose tissue as an endocrine organ. J. Clin. Endocrin. Metabol., 89(6): 2548-2556. DOI: 10.1210/jc.2004-0395

McCartney, C.R., Blank, S.K., Prendergast, K.A., Chhabra, S., Eagleson, C.A., Helm, K.D., Yoo, R., Chang, R.Y., Foster, C.M., Caprio, S., Marshall, J.C. (2007): Obesity and sex steroid changes across puberty: evidence for marked hyperandrogenemia in pre-and early pubertal obese girls. J. Clin. Endocrin. Metab., 92(2): 430-436. DOI: 10.1210/jc.2006-2002

Pápai, J. (1996): Sexual maturation and growth in the Jászság children. In: Bodzsár, É.B. (Ed.) Studies in Human Biology. Eötvös Univ Press, Budapest, 221-230.

Roemmich, J., Rogel, A. (1999): Hormonal changes during puberty and their relationship to fat distribution. Am. J. Hum. Bio., 11: 209-224. DOI: 10.1002/(SICI)15206300(1999)11:2<209::AID-AJHB9>3.0.CO;2-G

Rosenbaum, M., Leibel, R.L. (1999): Role of gonadal steroids in the sexual dimorphism in body composition and circulating concentrations of leptin. J. Clin. Endocrinol. Metab., 84(6): 1784-1789. DOI: 10.1210/jcem.84.6.5787

Sandhu, J., Ben-Shlomo, Y., Cole, T.J., Holly, J., Smith, G.D. (2006): The impact of childhood body mass index on timing of puberty, adult stature and obesity: a follow-up study based on adolescent anthropometry recorded at Christ's Hospital (1936-1964). Int. J. Obes., 30(1): 14-22. DOI: $\underline{10.1038 / \text { sj.ijo.0803156 }}$

Shuster, L.T., Rhodes, D.J., Gostout, B.S., Grossardt, B.R., Rocca, W.A. (2010): Premature menopause or early menopause: long-term health consequences. Maturitas, 65(2): 161-166. DOI: $10.1016 /$ j.maturitas.2009.08.003

Wells, J.C. (2007): Sexual dimorphism of body composition. Best Pract. Res. Clin. Endocrinol. Metab., 21(3): 415-430. DOI: 10.1016/j.beem.2007.04.007

World Health Organisation (2008): Waist circumference and waist-hip ratio. Report of a WHO expert consultation. Geneva, WHO.

Zhai, L., Liu, J., Zhao, J., Liu, J., Bai, Y., Jia, L., Yao, X. (2015): Association of obesity with onset of puberty and sex hormones in Chinese girls: a 4-year longitudinal study. PloSone, 10(8): e0134656. DOI: 10.1371/journal.pone.0134656

Zöllner, Y.F., Acquadro, C., Schaefer, M. (2005): Literature review of instruments to assess healthrelated quality of life during and after menopause. Qual. Life Res., 14(2): 309-327. DOI: 10.1007/s11136-004-0688-z 
Zsákai, A., Biri, B., Utczás, K., Fehér, P., Bodzsár, É. (2015) A női nemi hormonok koncentrációja és a testzsírosság változókorú nőknél. Anthropologiai Közlemények, 56: 139-151. DOI: 10.20330/AnthropKozl.2015.56.139

\section{Levelezési cím: $\quad$ Bodzsár Éva}

Mailing address: $\quad$ Embertani Tanszék, Eötvös Loránd Tudományegyetem

Pázmány s. 1/c.

H-1117 Budapest

Hungary

bodzsar@elte.hu 